\title{
Young students' views on problem solving versus problem posing
}

\author{
Jorryt van Bommel', Hanna Palmér ${ }^{2}$
}

\begin{abstract}
For decades, problem solving has been of interest to researchers, and several studies have tried to capture the influence of students' beliefs, attitudes and emotions towards mathematics and problem solving. However, problem posing as part of problem solving has not been investigated to the same extent. This article focuses on six-year-olds' views on solving and posing problems. How do the students themselves describe their views on solving and posing problem-solving tasks, and what similarities and differences can be found? An educational design research study was conducted in three classes where the students first solved and then posed problem-solving tasks. Afterwards, the students were interviewed. In these interviews the students expressed positive views towards both solving and posing problem-solving tasks. The students expressed autonomy and challenge as positive when both solving and posing tasks. However, a posed task needed to be solved before being finished. Further, not all students considered problem posing to be a mathematical activity, and a plausible explanation for this is the students' limited experience of problem posing.
\end{abstract}

\section{Article History}

Received: 12 October 2020

Accepted: 24 November 2020

\section{Keywords}

Problem posing; Problem

solving; Early childhood;

Mathematics

\section{Introduction}

Today there seems to be an international consensus that problem-solving education may start at an early age (Ellerton, Singer and Cai, 2015). This is reflected in the curricula in several countries where problem solving is implemented in kindergarten and preschool (e.g. National Agency for Education, 2017; 2018; The Stationery Office, 1999, Utdanningsdirektoratet, 2013). Problem solving includes both solving and posing problem-solving tasks (Niss and Højgaard, 2019), and for students to become competent problem solvers, problem-solving education ought to include both solving and posing problem-solving tasks. However, the focus in school mathematics has traditionally been on the solving part of problem solving only, and research on problem posing is still in its early years (Cai and Hwang 2020; Cai, Hwang, Jiang and Silber, 2015; Ellerton et al., 2015). Even though research has pointed out possible applications of problem posing at elementary school level (see for example Ellerton et al., 2015, and Lowrie, 2002), the majority of the research in this field still focuses on solving problem-solving tasks (Di Martino, 2019; English, 1998; English and Sriraman, 2010). This is why we know more about students' ability to solve problem-solving tasks than their ability to pose such tasks (Cai et al., 2015).

The empirical material in this article is from an intervention investigating the potential in using problem solving as the start for the mathematics education of six-year-olds in Sweden. In Sweden, six-yearolds have not yet begun formal schooling but attend what is called preschool class. The aim of preschool class is to facilitate a smooth transition between preschool and school and to prepare students for the next step of their education. The basis for the intervention was a national inspection showing that mathematics education offered limited opportunities for students to develop their ability to solve problems (Swedish Schools Inspectorate, 2009) even though both solving and posing problem-solving tasks are emphasised in the Swedish curriculum (National Agency of Education, 2018a). Despite the focus on both solving and

\footnotetext{
${ }^{1}$ Karlstad University, Faculty of Health, Science and Technology, Departmen of Mathematics and Computer Science, Karlstad, Sweden, e-mail: jorryt.vanbommel@kau.se, ORCID: https://orcid.org/0000-0001-6525-9871

${ }^{2}$ Linnaeus University, Faculty of Technology, Department of Mathematics, Växjö, Sweden, e-mail: hanna.palmer@lnu.se, ORCID: https://orcid.org/0000-0003-2217-6624
} 
posing problem-solving tasks in the Swedish curriculum, the intervention initially focused only on solving such tasks, where problem solving was both a purpose and a strategy. The intervention has been ongoing for several years and previous reports have shown positive results regarding students' learning of mathematics (Palmér and van Bommel, 2018a, 2018b; van Bommel and Palmér, 2018) as well as their feelings towards working on problem-solving tasks (Palmér and van Bommel, 2018c). The students had previously evaluated problem solving as fun and accessible, even in cases when their initial solutions were incorrect and they have had to struggle a lot to solve a task. Thus, understanding a task from the beginning or being able to solve it quickly are not necessarily prerequisites for young students to experience enjoyment when working with problem solving (Palmér and van Bommel, 2018c).

However, as both the Swedish curriculum and research have pointed out possible applications of problem posing at the elementary school level (e.g. Ellerton et al., 2015), we found a need to expand the intervention to also include problem posing. This article will focus on the first time problem posing was included in the intervention. Thus, the students were used to problem solving but to be able to pose a problem-solving task themselves, the students had to change perspective; instead of answering questions they were required to pose questions, and instead of interpreting information they needed to provide information. In this article, we will focus on the young students' views on problem posing and compare with their views on solving problem-solving tasks. Some cognitive but mainly emotional aspects of views will be focused on. 27 six-year-olds worked on both problem solving and problem posing, hence similarities and differences in their views on these two can be investigated. The following research question is elaborated on in the article:

- What similarities and differences can be found in young students' views on solving versus posing problem-solving tasks?

This question is of interest since previous studies have shown that students' emotional experiences may influence their process of solving non-routine mathematical tasks (Di Martino, 2019; Hannula, 2016; Passolunghi, Cargnelutti and Pellizzoni, 2019), and they may also influence how students view themselves as learners of mathematics as well as of other subjects (Clements and Sarama, 2016). This study adds to the limited research on problem posing (Cai et al., 2015) by providing insight into students' views on problem posing and whether there are, from the perspective of the students, any differences between solving and posing problem-solving tasks.

\section{Problem Solving and Problem Posing}

\section{Connection between problem solving and problem posing}

Research shows that a challenging level of the mathematical content can benefit students' learning (Claessens, Engel and Curran, 2014). However, such challenges are rare as routine tasks are more often included than challenging problem-solving tasks in early childhood education programmes (Cross, Woods and Schweingruber, 2009; Perry and Dockett, 2008). A task becomes a problem-solving task when the methods for solving are not known by the student beforehand. A problem-solving task is thus challenging as the student does not know in advance how to proceed to solve it. Instead, the student has to develop new (for him or her) strategies, methods and/or models to be able to solve the task (Cai, 2010; Lesh and Zawojewski, 2007). Offering a variation of problem-solving tasks to solve, where specific aspects are varied and other aspects are kept constant, will give the students an opportunity to distinguish the particular and discover the general (Peng, Li, Nie \& Li, 2017).

Brown and Walter (2004) put forward two reasons why problem posing and problem solving are connected. When solving a problem-solving task, new questions arise (e.g. What happens if...?; What if I were to...?), and these posed questions are a natural part of the problem-solving process. Further, in order to be able to pose problem-solving tasks, students need to shift sides and change perspective. To be able to construct a problem-solving task themselves, the students have to change perspective; instead of answering questions they are required to pose questions, and instead of interpreting information they need to provide information. The understanding of both the mathematical content and the solution per se may be deepened 
Young students' views on problem solving...

by posing problem-solving tasks, as students will have to operate on and modify the mathematical content. Modifying the content can of course be done without changing to problem posing.

Some researchers are more explicit and state that problem solving and posing are not only connected but include problem posing in the notion of problem solving (Niss and Højgaard, 2019). This implies problem posing as asking students to formulate, and thus to pose problem-solving tasks. Such problem posing in mathematics can cover reformulation, reconstruction and imitation (Kadir, Adelina and Fatma, 2018; Stoyanova, 2005). For Stoyanova (2005), reformulation means that the elements of the initial task are restructured by using different sentences. Reconstruction would incorporate a modification of the properties of the initial task through a change of content, whereas imitation goes further and is realised by adding and expanding the purpose. Similarly, Lee, Capraro and Capraro (2018) explain reformulation as one way to pose problems, and they write that problem posing can be done in two ways: through reformulation or through the generation of tasks. In both ways, students can investigate and develop knowledge of mathematical content and ideas. Reformulation, however puts a focus on students' reflection on the existing problem-solving task (Stickles, 2011). In contrast to reformulation as described by Stoyanova (2005), Lee et al. (2018) state that reformulation can mean asking students to pose a new task where either the structure or the method for solution remains similar to that in the initial problem-solving task.

One way to work on problem posing is to ask the students to pose a new problem-solving task with a structure similar to that of an initial task (Carrillo and Cruz, 2016). Cai and Hwang (2003) classified such posed problem-solving tasks as (1) extensive, having the same structure as the initial task but with higher mathematical demands; (2) not extensive, having the same structure and level as the initial task and (3) other, having a structure different from that of the initial task. Earlier, Leung (1997) used a similar classification distinguishing between posed problem-solving tasks that were mathematical and those that were not. In his classification Leung also included whether it would be possible to solve the given task and whether new mathematics would be needed. However, this does not mean that the students who pose the problems have to be able to solve the problem themselves (Lowrie, 2002).

Several researchers have pointed out that problem posing enriches the learners' experience and provides teachers and researchers with insights regarding students' understanding of the content taught (e.g. Carrillo and Cruz, 2016; Watson and Mason, 2002). When students for example are asked to produce a similar task, their understanding on the initial task can be revealed, providing the teacher with information on students' learning (Carrillo and Cruz, 2016). Thus, problem-solving tasks posed by students are not to be evaluated in terms of right or wrong but instead in terms of aspects such as structure (e.g. Carrillo and Cruz, 2016), the level of the mathematical content addressed (e.g. Cai and Hwang, 2003; Carrillo and Cruz, 2016) and also in terms of the information provided in the task (e.g. Leung, 1997). When students are asked to generate a problem-solving task there is no right problem-solving task to create. As such, problem posing can counteract the common view that there is one right way in mathematics. Further, a shift from solving to posing problem-solving tasks can be seen as a shift of control from others to oneself. Thus, problem posing may also promote a sense of autonomy and independence for students (Brown and Walter, 2004).

\section{Problem posing in the curriculum}

In Sweden, as well as in several other countries, problem solving has gained ground in the curriculum, and its emphasis has changed. In the past, students were encouraged to become problem solvers only after they had acquired the necessary mathematical knowledge needed to solve the tasks, nowadays the emphasis is on becoming a problem solver and how problem solving makes possible for students to acquire new mathematical knowledge (Boesen et al., 2014; Wyndhamn, Riesbeck and Schoultz, 2000). Working with problem solving will enable students to develop important mathematical ideas and competences (Csapó and Funke, 2017; Lesh and Zawojewski, 2007; Schoenfeld, 1992), and in order for students to become competent problem solvers, problem solving ought to be integrated in early childhood education instead of added after concepts and skills have been taught (Cai, 2010).

According to the Swedish curricula, problem solving is to be part of mathematics teaching from 
preschool onwards, continuing throughout all grades. When the curriculum changed in 2011, competences were introduced and problem posing became an explicit part of the curriculum: one of five competencies emphasized for elementary school mathematics is to "formulate and solve problems using mathematics and also assess selected strategies and methods" (National Agency for Education, 2017, p. 56). In preschool class the students are to be given conditions in which they can develop their abilities to experiment with and develop ideas, solve problems and put their ideas into action. Further, the students should be challenged and stimulated to use mathematical concepts and reasoning to communicate and solve problems (National Agency for Education, 2018a). Posing problem-solving tasks and solving problemsolving tasks are part of the curriculum for preschool and kindergarten as well (National Agency for Education, 2018a; 2018b).

\section{Investigating students' views}

Studies have shown that young students' achievement in science, technology, engineering, reading and mathematics is predicted by their interest in and feelings about mathematics and science (see for instance Clements and Sarama, 2016, for more details). In line with this, a special ESM issue on Affect and mathematics in young children was recently published in which "the importance of studying affect in young children who are in the early stages of acquiring formal mathematical skills" (Batchelor, Torbeyns and Verschaffel, 2019, p. 202) is emphasised. Leung (2013) has stated that (young) students' feelings towards problem posing are of importance for teachers to consider and several studies have tried to capture the influence of students' attitudes and emotions towards mathematics and problem solving. Some studies indicate that students' attitudes and emotions impact students' learning of mathematics (Di Martino, 2019; Giaconi, Varas, Tuohilampi and Hannula, 2016; Hannula, 2016; Mason and Johnston-Wilder, 2006; Schoenfeld, 1992) as well as students' interest in the subject (Clements and Sarama, 2016; Giaconi et al., 2016). For example, mathematics anxiety and mathematics difficulties are often connected to students' attitudes and feelings towards mathematics and problem solving (Antognazza, Di Martino, Pellandini and Sbaragli, 2015; Liljedal, 2017), indicating correlations between attitudes, emotions and performance in mathematics (Dowker, Bennett, and Smith, 2012; Giaconi et al., 2016). Feelings such as frustration, anxiety, confidence, surprise and curiosity have been shown to influence the process of solving non-routine mathematical tasks (Di Martino, 2019; Hannula, 2016; Passolunghi et al., 2019). However, there are also studies where no such correlations are found (Dowker et al., 2012; Pinxten, Marsh, De Fraine, Van Den Noortgate and Van Damme, 2013), or where correlations found might be explained through cultural differences in students' feelings towards mathematical problem solving (Dowker, Cheriton, Horton and Mark, 2019).

In studies on affect and mathematics, a wide range of constructs are used, for example beliefs, attitudes, and emotions as introduced by McLeod (1992). Of these, beliefs are seen as most cognitive and stable and least affective while emotions contrary are least cognitive, least stable and most affective (Hannula, Pantziara and Di Martino, 2018). Hannula (2011) has developed a model of affective constructs where the three dimensions of cognitive/affective/motivational, state/trait and psychological/social/embodied are combined illustrating the large variety of possible constructs in affective studies.

The intervention presented in this article takes a sociocultural perspective on mathematics teaching and learning which implies that knowing and doing mathematics is seen as a social and cultural practice (Rogoff, 2003). The learning of solving and posing problem-solving tasks is a process of increasing participation in the practice of problem solving and, through that participation, becoming knowledgeable in and about solving and posing problem-solving tasks (see also Lowrie, 2002). The students in the intervention presented here, had frequently participated in problem-solving activities. The focus of this article is on when these students are introduced to problem posing, an activity they had not participated in before. Them taking part in problem-posing activities can promote thinking and feelings in new directions and expand the students' participation in the social and cultural practice of school mathematics (e.g. Jakobsson, 2012). In line with this, the notion of views will be used in the study. Based on the above mentioned model of Hannula, views are affective (what one feels), state-type (dynamical) and developed 
Young students' views on problem solving...

in social practices. An individuals' views of a situation or a topic (for example solving and posing problemsolving tasks) includes what the individual feels and the ways the individual thinks of the specific situation. Thus, views includes aspects of cognitive as well as affective elements (Debellis and Goldin, 2006; Op't Eynde, DeCorte and Verschaffel, 2001; Wedege and Skott, 2006).

\section{Method}

The empirical material in this article is from one design cycle in the longitudinal intervention conducted in line with an educational design research. The aim of the intervention is to investigate the potential in using problem solving as the start for the mathematics education with six-year-olds in Sweden. The study started in 2014 and has been ongoing, involving more than 40 Swedish preschool classes from different schools and cities in different design cycles (see for example Palmér and van Bommel, 2018a, 2018b; van Bommel and Palmér, 2018, for more details on the different design cycles and their outcome). Common in educational design research studies is the iterative design (Prediger, Gravemeijer and Confrey, 2015), with the goal to develop theories that "guide, inform, and improve both practice and research" (Anderson and Shattuck, 2012, p. 16). Each design cycle includes preparing for teaching, implementation of the teaching, and finally, retrospective analysis of the teaching and learning (Cobb and Gravemeijer, 2008).

In this article, one specific design cycle on solving and posing a task within three-dimensional geometry is focused on with emphasis on student views on problem posing by reformulation. As this was the first time the students worked on problem posing, reformulation was chosen as it made it possible to explore students' reflection on the initial problem-solving task (Stickles, 2011). Also, reformulation gives students freedom to pose a new task where either the structure or the method for solution remains similar to the initial task. The design cycle was divided into two lessons and an individual follow-up interview.

\section{Selection of Preschool Classes}

Three preschool classes were selected for this design cycle based on their teachers' interest in participating. Two of the schools are located in an urban area and one in a rural area. In accordance with the Swedish Research Council's (2017) ethical guidelines, the students' guardians were informed about the study and they approved their children's participation. Altogether, 27 students from these preschool classes got approval and thus participated in the design cycle. The four teachers (two teachers work together in one of the preschool classes, thereof four teachers and three classes) working in these three preschool classes are educated as preschool teachers which implies that they have completed a three year university course in preschool teacher education. These teachers had participated in several of the previous design cycles and hence were familiar with problem solving, educational design research, and with the aim of the study. The teachers had taught mathematics through problem solving for some semesters why they had also implemented the problem-solving task on three-dimensional geometry several times before in other preschool classes. Problem posing was however new for both the teachers and the students.

\section{The Problem Solving and Problem Posing Lessons}

The two lessons were conducted in the usual classrooms of the three preschool classes. The lessons were designed in line with the previously described research on problem solving: the mathematical ideas were to be understandable, but the students should not have previously been taught a method for solving the tasks. In the first lesson, the students were to work on solving a problem-solving task, and in the second lesson they were to work on problem posing by reformulation by posing a similar problem to be given to a friend. By doing so, our focus on problem posing is very pragmatic and will provide only one experience to examine students' views. However, in order to be able to deepen these views a narrow focus helps us as the students in the interviews will refer to the same experience of problem posing. In the first lesson the students were handed a picture of a building (Figure 1). 

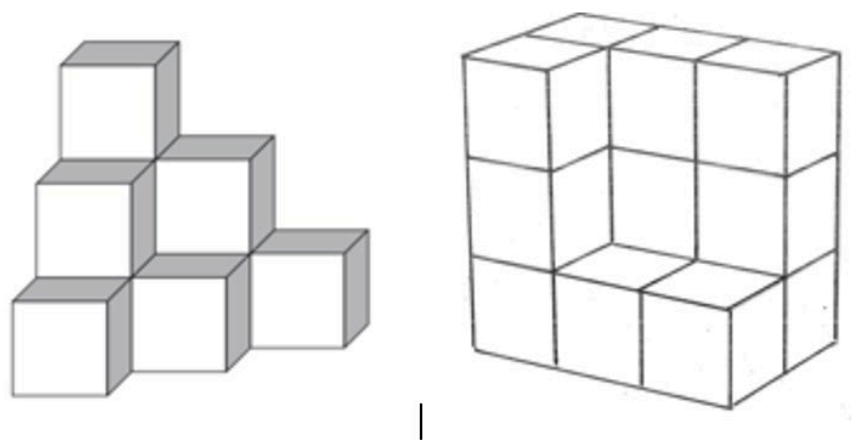

Figure 1. Pictures of the buildings used in the first lesson. (The building to the left is taken from http://ncm.gu.se/kangaru, Milou, 2008, question 9).

One of the preschool classes had previously worked with the building to the left in Figure 1, so they instead worked with the building to the right in Figure 1. The question asked was "How many blocks will you need to build the building?" The task deals with a two-dimensional representation of a threedimensional figure. To determine how many blocks they would need to build the building, the students had to imagine it from different perspectives. At first, they were to find a solution by themselves. After working by themselves the students were put in pairs to discuss and argue for their answers. In this phase of the lesson they were provided with blocks to build with, and a digital version of the building was also provided. The digital version provided an environment in which the students could build by swiping blocks to the building area and by doing so, creating a building similar to the one on paper. Once they built the building, they could manipulate the building by turning and twisting it. Further side views of the building were visible in this application ${ }^{3}$. Finally, in a joint whole-class discussion, the three-dimensional aspects of the building were discussed. One student (out of the 27) initially gave a correct answer to the question "How many blocks will you need to build the building?" Some of the answers from the other students indicated that they realised that there were more blocks than the visible ones. After building with blocks, all students explored the need for more blocks than the visible ones, and hidden blocks from different perspectives were explored in a whole-class discussion. This aligned with experiences from previous design cycles using this problem-solving task. Results from around 200 preschool class students show that even though only visible blocks are considered by the students initially, a large majority of the students give answers involving reasoning on the number of hidden blocks in follow-up interviews (see Palmér and van Bommel, 2018a).

The second lesson focused on problem posing. The students were first reminded of the problemsolving task they had worked on in the previous lesson, then they were asked to pose a similar problemsolving task to a friend. In accordance with the socio-mathematical norms (Yackel and Cobb, 1996) in these preschool classes, students could choose to work alone or with one or more classmates. As six-year-olds in Sweden have just started reading and writing, the task was given orally. The students were free to use blocks if they wanted, and no specific instructions were given about how to design their posed problemsolving task. If needed, the teachers helped the students to document the tasks they posed. If the students had built a building, these were photographed. Some groups of students took these photographs themselves, in other groups the teacher took the photograph making sure it captured what the students wanted it to capture. Paper-and-pen work as well as photographs of the buildings built by the students were collected at the end of both lessons. Together the students posed 14 tasks.

\section{Interviews}

To explore the students' views on solving versus posing problem-solving tasks, an interview was conducted one or some days after the second lesson. For practical reasons, the interviews had to be conducted when the rest of the students were involved in another activity thereof a difference in time. The 
Young students' views on problem solving...

decision to conduct interviews was based on the age of the students and the fact that they, in line with the Swedish school system, had just started reading and writing. Thus, writing would not be possible for most of the students, and drawings could get away from the focus of the exercise, leaving too much room for interpretation during the analysis. In the educational design research study as a whole, the teachers have been taking an active role and similar to previous design cycles they were the ones conducting the interviews. To obtain comparability with four teachers involved, a structured interview guide was used and the teachers were instructed, in writing and verbally by one of the researchers, on how to carry out the interviews and how to take notes.

In the interview, the students were asked of their views on the two lessons. As previous presented an individuals' views includes what one feels and ways of thinking. Table 1 presents examples of how the questions in the interview were connected to these two aspects. The questions in the interview were both open questions and questions where the students were to select between several pre-formulated alternatives. First in the interview the difficulty of solving and posing, as well as feelings while working on the two different types of tasks were addressed. The students were to finish sentence, for example - I think this task was... - by selecting among four alternatives: Super easy; Easy; Hard; Super hard (In Swedish: Jättelätt; Lätt; Svår; Jättesvår). As a follow-up question they were asked the open question, What, specifically, made the task super easy/easy/hard/super hard? The students were also asked questions about preferring problem solving or problem posing and reasons for their preferences as well as questions addressing their feelings when other students were to solve "their" task. Here the students got a positive statement, for example, I am happy when a friend can solve my task. Then they were to select one of four alternatives: Yes!; A bit; Well, not that much; No; I don't know (In Swedish: Ja!; Lite grann; Nja, inte så mycket; Nej!; Vet inte). After that, questions on mathematics, problem solving and problem posing in general were asked (ways of thinking). The students were asked if they knew what mathematics and problem solving were. These questions were asked because previous studies have shown that young students may not always have a good understanding of these words even though they have experience with both mathematics and problem solving (Di Martino, 2019). If the students said they knew what mathematics and problem solving was, they were shown tasks from the two lessons and asked if the two lessons involved mathematics and/or problem-solving.

Table 1. Examples, alternatives and number of questions in each aspect of the construct of views

\begin{tabular}{lllc}
\hline $\begin{array}{l}\text { Aspect of } \\
\text { views }\end{array}$ & Example of question & Alternatives & \multicolumn{1}{c}{$\begin{array}{l}\text { Total number of } \\
\text { questions }\end{array}$} \\
\hline $\begin{array}{l}\text { What } \\
\text { one } \\
\text { feels }\end{array}$ & I think this task was ... & Super easy; Easy; Hard; Super hard & 6 \\
$\begin{array}{l}\text { Ways } \\
\text { of } \\
\text { thinking }\end{array}$ & $\begin{array}{l}\text { What, specifically, made the task ... } \\
\text { (super easy/easy/hard/super hard) } \\
\text { Do you know what mathematics is? } \\
\text { If yes, what is it? }\end{array}$ & $\begin{array}{l}\text { A bit; Well, not that much; No; I don't } \\
\text { know }\end{array}$ & [No alternatives, open question] \\
\hline
\end{tabular}

The interview was tested in a pilot study where the choice of words was in focus; this was to make sure that the words used were related to the experiences of students at this age. Some adjustments in the formulation of alternatives were made after this pilot study (e.g. hard instead of difficult).

The interviews, together with the students' documentation from the two lessons, were analysed by the researchers (author 1, author 2). Based on the limited number of students, the analysis is qualitative, explorative and mainly on group level. First, each question was summarised and then patterns between questions were explored. Even though some means are presented in the results, the intention is not to make any statistical analysis, as a larger sample would be needed for this. 


\section{Results}

In the results we first shortly focus on the students' posed tasks in the second lesson. These solutions will serve as a background when presenting the data from the follow-up interviews as this lesson is the experience of problem posing of these students.

\section{The Second Lesson - Students Working on Problem Posing}

During the second lesson, when the students were to pose a similar task to a friend, the students had access to building blocks, paper and pens. As previously mentioned, they did not have to write their problem-solving task by themselves; instead, they could formulate it to their teacher, who wrote it down for them. All pairs/groups of students built a building with blocks, and all but one group posed a question connected to this building. The student who did not pose a problem-solving question was working by himself. He built a building with blocks but then said that it was not possible to pose a question. The other students both built a building and formulated a question, below are three examples of building built and questions posed by the students (Figure 2).

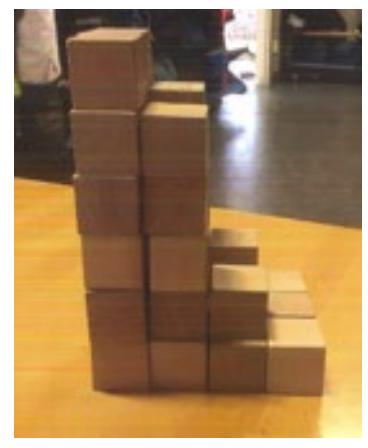

How many blocks are there in the building?

(Hur många klossar finns det i tornet?)

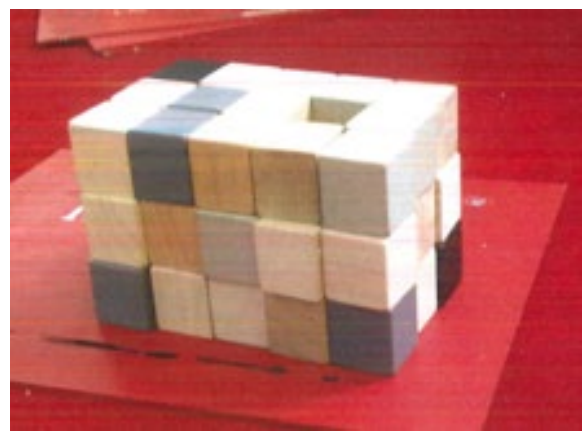

How deep is the hole if it has 42 blocks?

(Hur djupt är hålet om den har 42 klossar?)

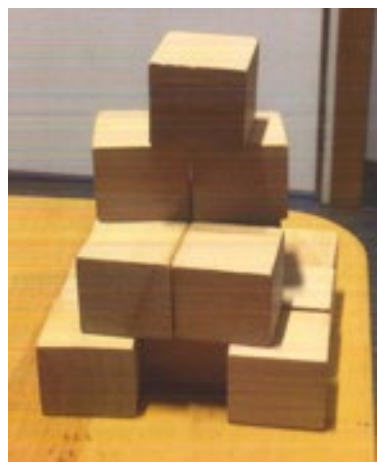

How do you make them talk?

(Hur får man dom att prata?)

Figure 2. Three examples of problem-solving tasks posed by students

These tasks are examples of the three categories of tasks created by the students: (1) a task based on a building and a similar mathematical question as in the initial task; (2) a task based on a building but a different kind of mathematical question than the original task and (3) a task based on a building but with a non-mathematical question. These categories are in line with Cai and Hwang's (2003) categories: not extensive (1), extensive (2) and other (3).

\section{The Follow-Up Interviews}

First in this section students answers on questions focused on ways of thinking will be presented and after that follows students answer on questions focused on what one feels.

On the question when a posed task is finished the majority (21) of the students thought that their posed task needed to be solved before they were finished with it. Thus, from the perspective of the students, it is not enough to pose a problem-solving task; for them to feel that their work is completed someone has to solve the task.

When asked what they would choose if they had to choose between solving and posing a problemsolving task, twelve of the students preferred to solve a problem-solving task, while 15 preferred to pose a problem-solving task. Of the students who preferred solving, several motivated this by saying that it is easy to solve. Other motives for choosing solving was it is quite exciting to think and I want to do clever things that someone else decides. There were however also students who answered that It is more difficult 
Young students' views on problem solving...

to make your own because then you have to do everything yourself and that this is why they preferred solving over posing. Motives for preferring to pose a problem-solving task included that it goes faster, it is much easier, you may decide completely by yourself, you can think of how to make it more difficult and you can do what you want. Thus, time is mentioned as a motive for choosing posing (goes faster to pose) while easy is mentioned as a motive for both solving and posing. For some of the students, the autonomy that goes with posing a problem-solving task seemed to be experienced as positive (you may decide completely by yourself), while autonomy for others was instead a motive for choosing to solve problemsolving tasks (It is more difficult to make your own because then you have to do everything yourself).

Seven students expressed not knowing what mathematics or problem solving was. The most common answer of the remaining 20 students to the question what mathematics is was to count. The most common answers to the question what problem solving is? were you ought to solve things that are tricky or you should solve problems. Table 2 summarises if the students considered solving a problem-solving task as well as posing a problem-solving task to be mathematics and/or problem solving.

Table 2. Students' views on solving and posing problem-solving tasks

\begin{tabular}{lcc}
\hline & Solving problem-solving tasks & Posing problem-solving tasks \\
\hline$\ldots$ is only mathematics & 1 & 2 \\
$\ldots$...is both mathematics and problem solving & 16 & 3 \\
$\ldots$...is only problem solving & 3 & 5 \\
$\ldots$..is neither one & - & 2 \\
No answer / don't know & - & 3 \\
\hline
\end{tabular}

16 of the students answered that solving a problem-solving task was both mathematics and problem solving. One student answered that solving a problem-solving task was mathematics but did not think it was problem solving, and another three students answered that solving a problem-solving task was problem solving but not mathematics. Related to posing a problem-solving task, eight of the students thought this was both mathematics and problem solving. Two students answered that posing a task was mathematics but not problem solving, and three answered that posing a task was problem solving but not mathematics. An argument for why problem posing was not problem solving was because you are the one who created the task. However, there were students who previous had explained problem solving in terms of you ought to solve things that are tricky or you should solve problems and who still considered both solving and posing problem-solving tasks to be mathematics as well as problem solving. Five students explicitly stated that posing a task was neither mathematics nor problem solving.

Thus, the students did not think about problem posing and problem solving in the same way with regard to whether the activities are mathematics or problem solving. Fewer students thought of posing a problem-solving task as mathematics and/or problem solving than solving a problem-solving task (13 and 20 respectively). Further, some students thought that posing was neither mathematics nor problem solving; although none of these (or other) students expressed this explicitly when asked about solving a problemsolving task.

Related to feelings, when the students were asked if it was fun to pose a problem-posing task to a friend to solve their answers were scattered on all response options (scale Yes! (4); A bit (3); Well, not that much (2); No (1) and I don't know (0)) but with a strong emphasis on the positive half (mean 3.58). Similarly, the students' answers to the statement I am happy when a friend can solve my task were positive (mean 3.79). The students also responded positively to the statements I am happy when a friend can solve my task (mean 3.79), Mathematics is fun (mean 3.39) and It is fun to solve problem-solving tasks (mean 3.68). Thus, the students expressed positive feelings towards both solving and posing problem-solving tasks. The students were also asked about their experienced difficulty of problem solving as well as the problem posing. The students thought that it was harder to pose a problem-solving task (mean 2.4) than to solve a 
problem-solving task (mean 2.23) but the difference was negligible (scale Super easy (1), Easy (2), Hard (3) or Super hard (4)). If connecting these answers to the students' answers to what they would choose if they had to choose between solving and posing, there were no clear pattern. There were students who expressed both solving and posing as either hard or easy and then motivate their selection of solving or posing by wanting to work hard or easy. There were also students who found posing harder than solving who preferred posing, and vice versa.

\section{Conclusion and Discussion}

While previous research provides quite rich knowledge on students' ability to and views on solving problem-solving tasks, there are more unanswered questions about students' ability to and views on problem posing (Cai et al., 2015). The questions elaborated on in this article concerned young students' views on problem posing, in specific: the feelings and ways of thinking of young students when being asked to reflect upon their own experience in problem posing. Since previous studies have shown that students' attitudes and emotions may have an influence on their solving of non-routine mathematical tasks (Di Martino, 2019; Hannula, 2016; Liljedahl, 2017; Passolunghi et al., 2019), and on how they view themselves as learners of mathematics and of other subjects (Clements and Sarama, 2016), these questions are of interest.

The results indicate that posing, just like solving problem-solving tasks (see Palmér and van Bommel, 2020), can be introduced in early childhood education. Even though this was the first time that these students were introduced to problem posing, all but one student posed a question. All categories of tasks - extensive, not extensive and other (Cai and Hwang, 2003) - were posed by the students. Further, the students expressed positive feelings towards both solving and posing. Solving and posing problem-solving tasks were equally popular amongst the students in the study: some students preferred to pose problemsolving tasks (15), while others preferred to solve such tasks (12). Autonomy (previously addressed by Brown and Walter (2004)) was put forward as one reason to prefer problem posing as students experienced their freedom to be able to choose as something positive. Conversely, autonomy was by other some students stated as negative in regard to problem posing as own creation was experienced as demanding and difficult compared to solving problem solving tasks.

Carrillo and Cruz (2016) emphasise that problem posing can provide insight into students' understanding, in this case of problem solving. Therefore, it is interesting to note that the same arguments were used by the students to express their preference for either posing or solving. For example, arguments related to time were given as a motive for preferring posing but also, by others for preferring solving. Another argument for the preference for either posing or solving was related to the difficulty, both when choosing solving and posing. Yet another argument used for both alternatives was autonomy, phrased as either the possibility to choose for oneself or the burden of having to choose. These arguments provide some insights in young students' views on both problem solving and problem posing and indicate that if both solving and posing become part of early childhood mathematics education this may attract a wider range of young students.

In order to become knowledgeable in posing problem-solving tasks, students need to be involved as participants in the practice of problem posing (Lowrie, 2002) and the students in this study were not accustomed to posing tasks, only to solving them. This might have influenced the students' answers on the question of when a posed task was finished: 21 of them thought that a posed task needed to be solved before they were finished with it. Also, fewer students thought posing (13) was mathematics, problem solving or both compared to those who thought solving was (20). There were even students (5) who thought that posing problem-solving tasks was neither mathematics nor problem solving. None of the students expressed this regarding solving problem-solving tasks. Thus, from the perspective of the students, it is not enough to pose a task: for them to feel that their work is completed, someone has to solve the task. Only few students thought that problem solving could consist of merely posing a problem-solving task without somebody solving it. A plausible explanation for this is the limited experience with problem posing of these specific students, especially compared to their experience in solving problem-solving tasks. Early 
Young students' views on problem solving...

childhood education provides an opportunity to enrich young students' problem solving skills via problem posing, as suggested in this article.

\section{Declarations}

Acknowledgements: We would like to thank the preschool class teachers Gunilla, Kristina, Lena and Åsa for their collaboration during the study.

Authors' contributions: Jorryt van Bommel and Hanna Palmér contributed equally to this paper.

Competing interests: The authors declare that they have no competing interests" in this section.

Funding: Not applicable

\section{References}

Anderson, T., \& Shattuck, J. (2012). Design-based research: A decade of progress in education research? Educational Researcher, 41(1), 16-25. https://doi.org/10.3102/0013189X11428813

Antognazza, D., Di Martino, P., Pellandini, A., \& Sbaragli, S. (2015). The flow of emotions in primary school problem solving. In K. Krainer, \& N. Vondrová (Eds.), Proceedings of the Ninth Congress of the European Society for Research in Mathematics Education (pp. 1116-1122). Prague: Charles University

Batchelor, S., Torbeyns, J., \& Verschaffel, L. (2019). Affect and mathematics in young children: An introduction. Educational Studies in Mathematics, 100(3), 201-209. https://doi.org/10.1007/s10649-018-9864-x

Boesen, J., Helenius, O., Bergqvist, E., Bergqvist, T., Lithner, J., Palm, T., \& Palmberg, B. (2014). Developing mathematical competence: From the intended to the enacted curriculum. The Journal of Mathematical Behavior, 33(1), $72-87$. https://doi.org/10.1016/j.jmathb.2013.10.001

Brown, S. I., \& Walter, I. M. (2004). The art of problem posing (3rd edition). Hillsdale, NJ: Lawrence Erlbaum Associates.

Cai, J. (2010). Commentary on problem solving heuristics, affect, and discrete mathematics: A representational discussion. In B. Sriraman, \& L. English (Eds.), Theories of mathematics education: Seeking new frontiers (pp. 251-258). Dordrecht: Springer. https://doi.org/10.1007/978-3-642-00742-2_25

Cai, J., \& Hwang, S. (2003). A perspective for examining the link between problem posing and problem solving. In N. A. Pateman, B. J. Dougherty, \& J. T. Zilliox (Eds.), Proceedings of the 2003 Joint Meeting of PME and PMENA: Vol. 3, (pp. 103-110). Honolulu, HI: University of Hawaii

Cai, J., \& Hwang, S. (2020). Learning to teach through mathematical problem posing: Theoretical considerations, methodology, and directions for future research. International Journal of Educational Research. https://doi.org/10.1016/j.ijer.2019.01.001

Cai, J., Hwang, S., Jiang C, \& Silber, S. (2015). Problem-posing research in mathematics education: Some answered and unanswered questions. In F. M. Singer, N. F. Ellerton, \& J. Cai (Eds.), Mathematical problem posing from research to effective practice (pp. 3-34). New York, NY: Springer. https://doi.org/10.1007/978-1-4614-6258-3_1

Carrillo, J., Cruz, J. (2016). Problem-posing and questioning: Two tools to help solve problems. In P. Felmer, E. Pehkonen, \& J. Kilpatrick (Eds.), Posing and solving mathematical problems: Advances and new perspectives (pp. 23-36). Cham, Switzerland: Springer. https://doi.org/10.1007/978-3-319-28023-3_2

Claessens, A., Engel, M., \& Curran, C. F. (2014). Academic content, student learning, and the persistence of preschool effects. American Educational Research Journal, 51(2), 403-434. https://doi.org/10.3102/0002831213513634

Clements, D. H., \& Sarama, J. (2016). Math, science, and technology in the early grades. The Future of Children, 26(2), 75-94.

Cobb, P., \& Gravemeijer, K. (2008). Experimenting to support and understand learning processes. In A. E. Kelly, R. A. Lesh, \& J. Y. Baek (Eds.), Handbook of design research methods in education: Innovations in science, technology, engineering, and mathematics learning and teaching (pp. 68-95). New York: Routledge.

Cross, C. T., Woods, T. A., \& Schweingruber, H. (2009). Mathematics learning in early childhood: Paths toward excellence and equity. Washington, DC: National Research Council of the National Academics.

Csapó, B., \& Funke, J. (Eds.). (2017). The nature of problem solving: Using research to inspire 21st century learning. Paris: OECD Publishing.

Debellis, V. A., \& Goldin, G. A. (2006). Affect and meta-affect in mathematical problem solving: A representational perspective. Educational Studies in Mathematics, 63(2), 131-147. https://doi.org/10.1007/s10649-006-9026-4

Di Martino, P. (2019). Pupils' view of problems: The evolution from kindergarten to the end of primary school. Educational Studies in Mathematics, 100(3), 291-307. https://doi.org/10.1007/s10649-018-9850-3

Dowker, A., Bennett, K., \& Smith, L. (2012). Attitudes to mathematics in primary school children. Child Development Research. 2012, 124939. https://doi.org/10.1155/2012/124939 


\section{Jorryt VAN BOMMEL \& Hanna PALMÉR}

Dowker, A., Cheriton, O., Horton, R., \& Mark, W. (2019). Relationships between attitudes and performance in young children's mathematics. Educational Studies in Mathematics, 100(3), 211-230. https://doi.org/10.1007/s10649-019-9880-5

Ellerton, N. F., Singer, F. M., \& Cai, J. (2015). Problem posing in mathematics: Reflecting on the past, energizing the present and foreshadowing the future. In F. M. Singer, N. F. Ellerton (Eds) Mathematical problem posing: From research to effective practice (pp. 547-556). New York, NY: Springer

English, L. (1998). Children's problem posing within formal and informal contexts. Journal for Research in Mathematics Education, 29(1), 83-106. https://doi.org/10.2307/749719

English, L., \& Sriraman, B. (2010). Problem solving for the $21^{\text {st }}$ century. In B. Sriraman, \& L. English (Eds.), Theories of mathematics education: Advances in mathematics education (pp. 263-283). Berlin Heidelberg: Springer.

Giaconi, V., Varas, M. L., Tuohilampi, L., \& Hannula, M. (2016). Affective factors and beliefs about mathematics of young Chilean children: Understanding cultural characteristics. In P. Felmer, E. Pehkonen, \& J. Kilpatrick (Eds.), Posing and solving mathematical problems. Advances and new perspectives. London: Springer.

Hannula, M. S. (2011). The structure and dynamics of affect in mathematical thinking and learning. In M. Pytlak, T. Rowland, \& E. Swoboda (Eds.), Proceeding of the Seventh Congress of the European Society for Research in Mathematics Education (pp. 34-60). Rzeszów, Poland: University of Rzeszów and ERME.

Hannula, M. S. (2016). Introduction. In G Kaiser (Ed.), Attitudes, beliefs, motivation and identity in mathematics education: An overview of the field and future directions (pp. 1-2). Cham, Switzerland: Springer.

Hannula, M., Pantziara, M., \& Di Martino, P. (2018). Affect and mathematical thinking. Exploring developments, trends, and future directions. In T. Drefys, M. Artigue, D. Potari, S. Prediger, \& K. Tuthven (Eds.), Developing research in mathematics education. Twenty years of communication, cooperation and collaboration in Europe. London: Routledge.

Jakobsson, A. (2012). Sociokulturella perspektiv på lärande och utveckling Lärande som begreppsmässig precisering och koordinering [Sociocultural perspectives on learning and development: Learning as conceptual clarification and coordination]. Pedagogisk Forskning i Sverige, 17(3-4), 152-170.

Kadir, Adelina, R., \& Fatma, M. (2018). Enhancing students' mathematical problem posing skill through writing in performance tasks strategy. Journal of Physics: Conference Series, 948, 1-7. https://doi.org/10.1088/1742-6596/948/1/012022

Lee, Y., Capraro, R. M., \& Capraro, M. M. (2018). Mathematics teachers' subject matter knowledge and pedagogical content knowledge in problem posing. International Electronic Journal of Mathematics Education, 13(2), 75-90. https://doi.org/10.12973/iejme/2698

Lesh, R., \& Zawojewski, J. (2007). Problem solving and modelling. In F. K. Lester (Ed.), Second handbook of research on mathematics teaching and learning (pp. 763-799). Charlotte, NC: National Council of Teachers of Mathematics and Information Age Publishing.

Leung, S. S. (1997). On the role of creative thinking in problem posing. ZDM - The International Journal on Mathematics Education, 97(2), $48-52$.

Leung, S. S. (2013) Teachers implementing mathematical problem posing in the classroom: Challenges and strategies. Educational studies in Mathematics, 83(1), 103-116. https://doi.org/10.1007/s10649-012-9436-4.

Liljedahl, P. (2017). On the edges of flow: Students engagement in problem solving. In T. Dooley, \& G. Gueudet. (Eds.), Proceeding of the Tenth Congress of the European Society for Research in Mathematics Education (pp. 1146-1153). Dublin, Ireland: DCU Institute of Education and ERME.

Lowrie, T. (2002). Designing a framework for problem posing: Young children generating open-ended tasks. Contemporary Issues in Early Childhood, 3(3), 354-363. https://doi.org/10.2304/ciec.2002.3.3.4

Mason, J., \& Johnston-Wilder, S. (2006). Designing and using mathematical tasks. St. Albans, UK: Tarquin.

McLeod, D. B. (1992). Research on affect in mathematics education: A reconceptualization. In D. A. Grouws (Ed.), Handbook of research on mathematics learning and teaching (pp. 575-596). New York, NY: MacMillan.

National Agency for Education. (2017). Curriculum for the primary school, preschool class and leisure time centre 2011. Stockholm: National Agency for Education.

National Agency for Education. (2018a). Curriculum for the compulsory school, preschool class and school-age educare. Stockholm: National Agency for Education.

National Agency for Education. (2018b). Curriculum for the preschool. Stockholm: National Agency for Education.

Niss, M., \& Højgaard, T. (2019). Mathematical competencies revisited. Educational Studies in Mathematics, 102, 9-28. https://doi.org/10.1007/s10649-019-09903-9

Op't Eynde, P., De Corte, E., \& Verschaffel, L. (2001). "What to learn from what we feel?": The role of children's emotions in the mathematics classroom. In S. Volet, \& S. Järvelä (Eds.), Motivation in learning contexts: Theoretical advances and methodological implications (pp. 149-167) (Advances in Learning and Instruction Series.). Oxford, UK: Elsevier Science. 
Young students' views on problem solving...

Palmér, H., \& van Bommel, J. (2018a). Problem solving in early mathematics teaching: A way to promote creativity? Creative Education, 9(10), 1775-1793. https://doi.org/10.4236/ce.2018.912129

Palmér, H., \& van Bommel, J. (2018b). The role of and connection between systematization and representation when young children work on a combinatorial task. European Early Childhood Education Research Journal, 26(4), 562-573. https://doi.org/10.1080/1350293X.2018.1487141

Palmér, H., \& van Bommel, J. (2018c). Young children's feelings towards problem-solving tasks: What does "success" imply? In B. Rott, G. Törner, J. Peters-Dasdemir, A. Möller, \& Safrudiannur (Eds.), Views and beliefs in mathematics education: The role of beliefs in the classroom (pp. 69-78). Cham: Springer.

Palmér, H., \& van Bommel, J. (2020). Young students posing problem-solving tasks: What does posing a similar task imply to students? ZDM - the International Journal on Mathematics Education, 52(4), 743-752. https://doi.org/10.1007/s11858-020-01129-x

Passolunghi, M., Cargnelutti E., \& Pellizzoni, S. (2019). The relation between cognitive and emotional factors and arithmetic problemsolving. Educational Studies in Mathematics, 100(3), 271-290. https://doi.org/10.1007/s10649-018-9863-y

Peng, A., Li, J., Nie, B., \& Li, Y. (2017). Characteristics of teaching mathematical problem solving in China. In R. Huang, \& Y. Li (Eds.), Teaching and learning mathematics through variation. Mathematics teaching and learning (pp. 111-125). Rotterdam: Sense Publishers.

Perry, B., \& Dockett, S. (2008). Young children's access to powerful mathematical ideas. In L. D. English (Ed.), Handbook of international research in mathematics education (pp. 75-108). New York, NY: Routledge.

Pinxten, M., Marsh, H. W., De Fraine, B., Van Den Noortgate, W., \& Van Damme, J. (2013). Enjoying mathematics or feeling competent in mathematics? Reciprocal effects on mathematics achievement and perceived math effort expenditure. British Journal of Educational Psychology, 84(1), 152-174. https://doi.org/10.1111/bjep.12028

Prediger, S., Gravemeijer, K., \& Confrey. J. (2015). Design research with a focus on learning processes: An overview on achievements and challenges. ZDM Mathematics Education, 47(6), 877-891. https://doi.org/10.1007/s11858-015-0722-3

Rogoff, B. (2003). The cultural nature of human development. Oxford: Oxford University Press.

Schoenfeld, A. (1992). Learning to think mathematically: Problem solving, metacognition, and sense making in mathematics. In D. A. Grouws (Ed.), Handbook of research on mathematics teaching and learning (pp. 165-197). New York: MacMillan.

Stickles, P. (2011). An analysis of secondary and middle school teachers' mathematical problem posing. Investigations in Mathematics Learning, 3(2), 1-34. https://doi.org/10.1080/24727466.2011.11790301

Stoyanova, E. (2005). Problem-posing strategies used by years 8 and 9 students. Australian Mathematics Teacher, 61(3), 162-175.

Swedish Research Council. (2017). Good custom in research. Stockholm: Vetenskapsrådet.

Swedish Schools Inspectorate. (2009). The teaching of mathematics: The content and the effectiveness of the education. Kvalitetsgranskning rapport 2009:5. Stockholm: Skolinspektionen.

The Stationery Office. (1999). Primary school curriculum: Mathematics. Dublin: The Stationery Office.

Utdanningsdirektoratet. (2013). Læreplan i matematikk fellesfag. Retrieved from http://data.udir.no/k106/MAT1-04.pdf

van Bommel, J., \& Palmér, H. (2018). Enhancing young children's understanding of a combinatorial task by using a duo of digital and physical artefacts. Early Years. https://doi.org/10.1080/09575146.2018.1501553

Watson, A., \& Mason, J. (2002). Student-generated examples in the learning of mathematics. Canadian Journal of Science, Mathematics, and Technology Education, 2(2), 237-249. https://doi.org/10.1080/14926150209556516

Wedege, T., \& Skott, J. (2006). Changing views and practices? A study of the KappAbel mathematics competition. Trondheim: Matematikcentret.

Wyndhamn, J., Riesbeck, E., \& Schoultz, J. (2000). Problemlösning som metafor och praktik [Problem solving as a metaphor and practice]. Institutionen för tillämpad lärarkunskap: Linköpings Universitet.

Yackel, T., \& Cobb, P. (1996). Sociomathematical norms, argumentation, and autonomy in mathematics. Journal for Research in Mathematics Education, 27(4), 458-477. https://doi.org/10.2307/749877 